IRA-International Journal of Management \& Social Sciences

ISSN 2455-2267; Vol.15, Issue 03 (June, 2019)

Pg. no. 81-87.

Institute of Research Advances

http://research-advances.org/index.php/RAJMSS

\title{
Effectiveness of NGOs and Quality of Life of the Beneficiaries
}

\section{Dr K. Balaraju}

Assistant Professor (c), Department of Social Work, Osmania University, India.

Type of Work: Peer Reviewed.

DOl: http://dx.doi.org/10.21013/jmss.v15.n3.p3

\section{How to cite this paper:}

Balaraju, K. (2019). Effectiveness of NGOs and Quality of Life of the Beneficiaries. IRAInternational Journal of Management \& Social Sciences (ISSN 2455-2267), 15(3), 81-87. doi:http://dx.doi.org/10.21013/jmss.v15.n3.p3

\section{(C) Institute of Research Advances.}

\section{(cc) EY-NC}

This work is licensed under a Creative Commons Attribution-Non Commercial 4.0 International License subject to a proper citation to the publication source of the work.

Disclaimer: The scholarly papers as reviewed and published by the Institute of Research Advances (IRA) are the views and opinions of their respective authors and are not the views or opinions of the IRA. The IRA disclaims of any harm or loss caused due to the published content to any party.

Institute of Research Advances is an institutional publisher member of Publishers International Linking Association Inc. (PILA-CrossRef), USA. The institute is an institutional signatory to the Budapest Open Access Initiative, Hungary advocating the open access of scientific and scholarly knowledge. The Institute is a registered content provider under Open Access Initiative Protocol for Metadata Harvesting (OAI-PMH).

The journal is indexed \& included in WorldCat Discovery Service (USA), CrossRef Metadata Search (USA), WorldCat (USA), OCLC (USA), Open J-Gate (India), EZB (Germany) Scilit (Switzerland), Airiti (China), Bielefeld Academic Search Engine (BASE) of Bielefeld University, Germany, PKP Index of Simon Fraser University, Canada. 


\begin{abstract}
Organizational effectiveness influences the NGOs performance in various important aspects like stakeholders' satisfaction, expertise solutions in their area of operation, goal achievement and innovation. NGOs operate in order to improve their beneficiaries' quality of life aspects. The present study focuses on the relationship between the effectiveness of NGOs and the quality of life experiences of their beneficiaries. Using standard stratified disproportionate random sampling method $10 \mathrm{NGOs}$ were selected, further from the sample list of 10 NGOs 100 staff members and 300 beneficiaries were selected for the purpose of the present study. The result indicated that the effectiveness of NGOs and QOL of the beneficiaries are positively and significantly correlated. To be more specific "Programme Effectiveness", as a dimension of the effectiveness of NGOs was the strongest correlate of QOL, followed by "Agency Appreciation”, “ Innovation" and "Grass Root Impact". All the least correlated dimensions are "Target Group Involvement" and "Resource Appreciation".
\end{abstract}

Key Words: NGOs, Organizational Effectiveness, Quality of Life, Beneficiaries

\title{
Introduction
}

Leadership in NGO sector is different from leadership in the profit sector, where the NGOs have been working not for profit at the same time trying to fulfil the needs of needy people and vulnerable sections of the society. NGOs are considered to have a moral obligation to act in the public interest, they are also accountable for what they say and the positions they take on particular issues (Slim, 2002). Since the early 1990s, the reference of "accountability" has been ascendant, with demands from funders, taxpayers, and concerned citizens and clients for non-profits to be more transparent about their fundraising and spending, how they are governed, and what they have achieved with the resources entrusted to them (Ebrahim\&Weisband, 2007). The question of performance has to do with the quality versus the quantity of NGO services (Jordan, 2003). Since they question the performance of governments for the way they spend public funds, NGOs are also asked to show that they have done better with the money that they received. These organisations do not have a clear bottom line to determine how well they are achieving their mission. Instead, program evaluations assess whether they are achieving explicit program goals and satisfying their clients. NGO effectiveness is multi-dimensional and cannot be assessed with a single indicator.

Measuring overall organizational effectiveness is an important issue which has been insufficiently researched. Determining whether an organization has been able to align their organizational processes with the programmatic impacts is necessary to assess their degree of success. Evaluating impacts and identifying indicators of organizational success are necessary to report to the public, funders and to improve the organization's level of effectiveness.

Assessing the effectiveness of NGOs will help to focus more effectively on planned outcomes. Such outcomes might improve the socio-economic status of the beneficiaries and eventually provide quality of life experiences. Understanding the effectiveness of NGOs contributes to the development of their operational area and also to the beneficiaries.

Quality of life is a holistic approach that not only emphasizes on individuals' physical, psychological, and spiritual functioning but also their connections with their environments; opportunities for maintaining and enhancing skills. Researchers have varied definitions of the concept of quality of life, because the quality of life is a multidimensional concept (Ferrans, 1996, Kemppainen, 2001; Phalaze 2005; WHOQOL, 1995; Wilson \& Clearly, 1995; Robinson, 2004). Quality of life basically is of two factors namely subjective and objective. Objective quality of life is considered to be of material benefits which help people fulfil their needs, whereas, the subjective QOL is more of perception of the ideal experiences of life. In this study, subjective QOL is adopted. Therefore the present study contributes towards understanding quality of life experiences of NGO's beneficiaries.

This study also contributes to understanding the relationships between the NGOs effectiveness and quality of life of their beneficiaries. Earlier research profusely contributed to the understanding about NGOs efforts in improving 
socio economic status of the beneficiaries. Causing a huge void research on NGOs work towards beneficiaries' quality of life, such concerns are addressed in this study.

\section{Purpose of the study}

Quality of life of the NGOs' beneficiaries has been grossly underrepresented in previous research on NGOs around the world in general and in India in specific. The reason for such a gap in research could be the undisputed focus on understanding socio-economic development of the NGOs beneficiaries rather than their quality of life experiences. The main purpose of the study is to evaluate and explore the relationship between the organizational effectiveness of NGOs and the quality of life experience of their beneficiaries.

\section{Literature Review}

Freeman, (1985) opined that the donor agencies largely depended on annual progress reports which are gain "success stories". They do send evaluators or expert teams for assessment of the performance and outcome of the NGO activities. NGO Activities are experimental and innovations rather than routine, in such circumstances measuring NGO effectiveness is not an easy one, here evaluators have to choose a variety of evaluation systems and tools rather than any one approach.

Shilbury\& Moore (2006) conducted an empirical study of the effectiveness of 28 Australian National Olympic Sporting Organisations using the competing values approach. They firstly noted the confusion over a definition of effectiveness but did little to clarify the issue. They also noted that the focus on effectiveness was largely driven by increased government funding and the implied requirement for accountability.

Khagram et al., (2009) contends that some of these methods draw on recent advances in comparative case study designs that enable cautious causal inferences to be drawn while also elaborating interactive causal mechanisms and processes. A primary contention of this new suite of evaluation approaches is that isolating causal factors and measuring impact is not enough, even in the limited circumstances when it is feasible; rather, policymakers and development managers need an integrated set of assessment methods that can help them build, refine and adapt their interventions in real time.

Cummins (1996) has suggested seven domains (Material well-being, Emotional well-being, Productivity, Intimacy, Safety, Community and Health) capture the 'totality' of the QOL constructs. However, Cummins has recently advanced a theory of subjective well-being which radically recasts the concept.

Schalock, Robert L (2004) stated that Quality of life emerged as an academic discipline in its own right in the 1970s, with the establishment in 1974 of the peer-reviewed scientific journal Social Indicators Research, founded and edited by Alex Michalos. Since then the volume of academic articles concerned with QOL and well-being issues has steadily increased. Schalockreports that since 1985 alone over 20,900 academic articles have appeared in the international literature containing the term "quality of life" in their title.

According to (Quality of life research unit, University of Toronto (2005)Standards of Living is a measure of the quantity and quality of goods and services available to people. It measures such aspects as GDP Per Capita, life expectancy, Births/1000, Infant Mortality/1000, Doctors/1000, Cars/1000, TV/1000, Telephones/1000, Literacy levels, \%GDP spent on Education, \%GDP spent on Health, Cinema attendance, newspaper circulation, Fertility Rate, Density, Population per dwelling, etc. Quality of Life is the product of the interplay among social, health, economic and environmental conditions which affect human and social development.

Gregory, Derek; Johnston, Ron; Pratt, Geraldine et al, eds. (2009) stats that Quality of life should not be confused with the concept of standard of living, which is based primarily on income. Instead, standard indicators of the quality of life include not only wealth and employment, but also the built environment, physical and mental health, 
education, recreation and leisure time and social belonging. It is difficult to use one universal way of measuring the quality of life across countries and within individuals.

KahnemanandDeuton, (2010) concluded that recent research began to distinguish two aspects of Subjective Well Being. Emotional Well Being refers to the emotional quality of life an individual's everyday experience. The frequency and intensity of experiences of joy, stress, sadness, anger and affection that makes one's life pleasant or unpleasant. Life evaluation refers to the thoughts that people have about their life when they think about it. In their recent study

The extant literature on Nongovernmental Organizations effectiveness is intended to identify and describe some of the key components in creating and maintaining successful non-profit organizations. Literature highlights that NGOs are in fact playing a role in helping beneficiaries to achieve human development. Further literature shows how human development leads to the quality of life. It is interesting to mention that while NGOs are trying to improve the quality of life through increased human development; there are instances where they are directly trying to improve the quality of life aspects as well. However, the instances where the role of NGOs have been evaluated or studied from the perspective of beneficiaries are very rare.

The present study does not deal with the evaluation of the programmes conducted by the NGOs, but the evaluation of NGOs in the perspective of how effective are they as organisations in the eyes of their employees and the beneficiaries as well.

\section{The methodology of the study\& Sampling}

Using descriptive and analytical research design this study addresses the organizational effectiveness of NGOs and the influence of organizational effectiveness on the quality of life of the beneficiaries of NGOs. The present study carried out in Telangana. Using standard stratified disproportionate random sampling method 10 NGOs were selected, further from the sample list of 10 NGOs 100 staff members and 300 beneficiaries were selected for the purpose of the present study. The objective of the study

To explore the relationship between organizational effectiveness of Nongovernmental organizations and the quality of life of their beneficiaries

\section{Hypothesis}

There is no relationship between the effectiveness of NGOs and the quality of life of their beneficiaries.

\section{Tools of Data Collection}

A standardized questionnaire (28 items scale) adapted to measure Organisation Effectiveness of NGOs developed by SwapanGarain (1993) and additionally 3 items have been included to make it 31 item scale. The further structured interview schedule was prepared for the NGOs beneficiaries to respond. This interview schedule consisted the two parts Part A elicits data relating to their personal background and Part B includes an 18 items standardized scale to assess QOL of the beneficiary developed by Quality of Life Research Unit, (Raphael, et.al 1998) has been adopted in the study. Details of the scale are presented in table 1 
Table 1: Details of Scale to Assess QOL

\begin{tabular}{|c|c|c|c|c|c|}
\hline SNo & $\begin{array}{c}\text { QOL } \\
\text { Dimension }\end{array}$ & Sub Dimensions & Statements & $\begin{array}{l}\text { No. of } \\
\text { Items }\end{array}$ & Alpha \\
\hline \multirow{6}{*}{1} & \multirow{6}{*}{ Being } & \multirow{2}{*}{ Physical Being } & Being physically able to get around. & \multirow{2}{*}{2} & \multirow{2}{*}{.52} \\
\hline & & & My nutrition and the food I eat. & & \\
\hline & & \multirow{2}{*}{$\begin{array}{l}\text { Psychological } \\
\text { Being }\end{array}$} & Being free of worry and stress. & \multirow{2}{*}{2} & \multirow{2}{*}{.55} \\
\hline & & & The mood I am usually in. & & \\
\hline & & \multirow{2}{*}{ Spiritual Being } & Having hope for the future. & \multirow{2}{*}{2} & \multirow{2}{*}{.54} \\
\hline & & & My own ideas of right and wrong. & & \\
\hline \multirow{6}{*}{2} & \multirow{6}{*}{ Belonging } & \multirow{2}{*}{$\begin{array}{l}\text { Physical } \\
\text { Belonging }\end{array}$} & The house or apartment I live in. & \multirow{2}{*}{2} & \multirow{2}{*}{.53} \\
\hline & & & The neighbourhood I live in. & & \\
\hline & & \multirow{2}{*}{ Social Belonging } & Being close to people in my family. & \multirow{2}{*}{2} & \multirow{2}{*}{.50} \\
\hline & & & Having a spouse or special person. & & \\
\hline & & \multirow[t]{2}{*}{$\begin{array}{l}\text { Community } \\
\text { Belonging }\end{array}$} & $\begin{array}{l}\text { Being able to get professional services } \\
\text { (medical, social, etc.) }\end{array}$ & \multirow[t]{2}{*}{2} & \multirow[t]{2}{*}{.52} \\
\hline & & & Having enough money. & & \\
\hline \multirow{6}{*}{3} & \multirow{6}{*}{ Becoming } & \multirow{2}{*}{$\begin{array}{l}\text { Practical } \\
\text { Becoming }\end{array}$} & Doing things around my house. & \multirow{2}{*}{2} & \multirow{2}{*}{.53} \\
\hline & & & Working at a job or going to school. & & \\
\hline & & \multirow{2}{*}{$\begin{array}{l}\text { Leisure } \\
\text { Becoming }\end{array}$} & Outdoor activities (walks, cycling, etc.) & \multirow{2}{*}{2} & \multirow[b]{2}{*}{.49} \\
\hline & & & Indoor activities (TV, cycling, etc.) & & \\
\hline & & \multirow[b]{2}{*}{$\begin{array}{l}\text { Growth } \\
\text { Becoming }\end{array}$} & Improving my physical health and fitness. & \multirow[b]{2}{*}{2} & \multirow{2}{*}{.55} \\
\hline & & & Being able to cope with changes in my life. & & \\
\hline
\end{tabular}

(Source: Adapted from University of Toronto, CHP, QOL research unit: 1998)

\section{Testing of Hypothesis}

As it was hypothesized "There is no relationship between the effectiveness of NGOs and the quality of life of their beneficiaries. In order to test hypotheses, multiple regression analysis was conducted treating the effectiveness of NGOs as an independent variable, Quality of Life was treated as a dependent variable. Results pertaining to the testing of hypotheses are presented in table 2 . 
Table 2: Predictions and Estimates for Effectiveness of NGOs on QOL of the Beneficiaries (Dependent Variable $=$ Quality of Life)

\begin{tabular}{|c|c|c|c|c|c|c|c|c|}
\hline \multicolumn{3}{|c|}{ Model } & $\mathrm{r}$ & $\begin{array}{l}\text { Unstandardized } \\
\text { Coefficients }\end{array}$ & $\begin{array}{l}\text { Standardized } \\
\text { Coefficients }\end{array}$ & & \multirow{2}{*}{\multicolumn{2}{|c|}{ Sig. }} \\
\hline & & & & Std. Error & Beta & $\mathrm{t}$ & & \\
\hline 1 & \multicolumn{2}{|c|}{ (Constant) } & & .436 & & .785 & \multicolumn{2}{|r|}{.435} \\
\hline 2 & \multicolumn{2}{|c|}{ Agency Appreciation } & $.51 * *$ & .014 & .180 & 2.726 & \multicolumn{2}{|r|}{.008} \\
\hline 3 & \multicolumn{2}{|c|}{ Program Effectiveness } & $.39 * *$ & .014 & .087 & 1.373 & \multicolumn{2}{|r|}{.173} \\
\hline 4 & \multicolumn{2}{|c|}{ Innovation } & $.39^{* *}$ & .019 & .155 & 2.169 & \multicolumn{2}{|r|}{.033} \\
\hline 5 & \multicolumn{2}{|c|}{ Grassroots Impact } & $.39^{* *}$ & .020 & .147 & 1.839 & \multicolumn{2}{|r|}{.050} \\
\hline 6 & \multicolumn{2}{|c|}{ Resource Appreciation } & $.28^{* *}$ & .029 & .819 & 10.910 & \multicolumn{2}{|r|}{.000} \\
\hline 7 & \multicolumn{2}{|c|}{ Project Orientation } & $.60^{* *}$ & .023 & .156 & 2.885 & \multicolumn{2}{|r|}{.037} \\
\hline 8 & \multicolumn{2}{|c|}{$\begin{array}{l}\text { Target Group } \\
\text { Involvement }\end{array}$} & $.30^{* *}$ & .030 & .092 & .134 & \multicolumn{2}{|r|}{.397} \\
\hline 9 & \multicolumn{2}{|c|}{ Organization Flexibility } & $.38^{* *}$ & .023 & .028 & .420 & \multicolumn{2}{|r|}{.676} \\
\hline Model & $\mathbf{R}$ & R Square & & isted R Square & F-value & & d.f & $\mathbf{P}=$ \\
\hline 1 & $.834^{a}$ & .695 & & .668 & 25.95 & & 8,99 & 0.000 \\
\hline
\end{tabular}

\section{Major Findings of the study}

1. Effectiveness of NGOs and QOL of the beneficiaries are positively and significantly correlated. Indicating that the effectiveness of NGOs strong correlate of beneficiaries Quality of life. All these evident from the multiple $\mathrm{R}=0.83$. To be more specific all the dimensions "Programme Effectiveness", as a dimension of effectiveness of NGOs was the strongest correlate of QOL ( $\mathrm{r}=0.80, \mathrm{p}=0.00)$, followed by "Agency Appreciation", $(\mathrm{r}=0.5, \mathrm{p}=0.00)$, "Programme Effectiveness", “Innovation" and "Grass root Impact", $(\mathrm{r}=0.39, \mathrm{p}=0.00)$. All the least correlated dimensions are "Target Group Involvement", $(\mathrm{r}=0.30, \mathrm{p}=0.00)$, "Resource Appreciation" ( $\mathrm{r}=0.30, \mathrm{p}=0.00)$.

2. With regard to beta coefficients "Resource Appreciation", "Agency Appreciation", "Innovation", "Project Orientation", and "Grass root Impact" yielded positive and significant beta coefficient. In other words, all of these dimensions have an independent effect on QOL. Surprisingly "Project Orientation", "Target Group Involvement", and "Organisation Flexibility did not yield significant betas. 
3. To be more specific if "Resource Appreciation" "improves by one unit 0.8 units of QOL increases significantly, similarly " Agency Appreciation" would contribute 0.18 units, "Innovation" 0.15 units " Grass root Impact 0.14 units, "Programme Effectiveness" 0.15 units to QOL of the beneficiaries.

4. Lastly, the coefficient of determination yielded a value of 0.69 , when it was adjusted for all the errors the value yielded 0.66, this indicates that all the dimensions of Effectiveness of NGOs put together explain 66 per cent of the variance in beneficiaries QOL. Interestingly such value is also statistically significant $(\mathrm{F}=25.29, \mathrm{DF}=8,99, \mathrm{p}=0.00)$. Thus the null hypothesis is stands rejected and the alternative hypothesis is accepted. In other words, beneficiaries Quality of life very much determined by the effectiveness of NGOs.

The null hypothesis stands rejected and the alternative hypothesis is accepted.

\section{Conclusion}

It was found that the effectiveness of NGOs and quality of life of the beneficiaries are positively and significantly correlated; indicating that the effectiveness of NGOs determines beneficiaries' quality of life. Coefficient of determination computed, reveal that nearly 66 per cent of change in the quality of life of the beneficiaries is explained by the dimensions of NGO effectiveness, indicating that indeed, NGOs effectiveness is the strong predictor of quality of life of the beneficiaries. This further indicates that the quality of life of the beneficiaries in rural areas of Telangana can be ensured to them only by the NGOs which are effective in all aspects of their structure and processes.

\section{References}

[1]. Cummins, R. A. (1996) The Domains Of Life Satisfaction: An Attempt To Order Chaos, Social Indicators Research, 38: 303-28.

[2]. Ebrahim, A., \&Weisband, E. (Eds.) (2007), Global Accountabilities. Participation, Pluralism, And Public Ethics. Cambridge: Cambridge University Press.

[3]. Freeman (1985), Evaluation: A Systematic Approach. Beverly Hills, CA, Sage Publications.

[4]. Ferrans, C. E. (1996), Development of Conceptual models of Quality of Life, Scholarly inquiry for nursing practice: An International Journal, 10(3).

[5]. Gregory, Derek; Johnston, Ron; Pratt, Geraldine Et Al, Eds. (June 2009). "Quality of Life". Dictionary of Human Geography (5th Ed.). Oxford: Wiley-Blackwell. ISBN 978-1-4051-3287-9

[6]. Kahneman, D, Deaton, A. (2010) "High Income Improves Evaluation Of Life But Not Emotional Wellbeing”. Proceedings Of The National Academy Of Sciences 107 (38)

[7]. Kemppainen, J. K. (2001). Predictors of Quality Of Life In AIDS Patients. JANAC: Journal of The Association Of Nurses In AIDS Care, 12(1), 61-70.

[8]. Khagram, S., Thomas, C., Lucero, C., \&Mathes, S. (2009). Evidence for Development Effectiveness. Journal Of Development Effectiveness, 1(3): 247-270.

[9]. Phaladze, N. A (2005). Quality Of Life and Concept Of 'Living Well' With HIV/AIDS in Sub-Saharan Africa. Journal of Nursing Scholarship, 37(2), 120-127.

[10]. Robinson, P. F. (2004). Measurement of Quality of Life. Journal of Association of Nurses in AIDS Care, 15, 14S-19S.

[11]. Schalock, Robert L (2004) 'The Concept Of Quality Of Life: What We Know And Do Not Know', Journal Of Intellectual Disability Research, 48, 3, P205.

[12]. Shilbury, D. \& Moore, K.A. (2006). A study of organizational effectiveness for National Olympic Sporting Organizations. Nonprofit and Voluntary Sector Quarterly, 35(1), 5-3

[13]. Slim, H., (2002), "By What Authority? The Legitimacy And Accountability Of Non-Governmental Organisations", The Journal Of Humanitarian Assistance, (Electronic).Http://Www.Jha.Ac/Articles/A082.Htm.

[14]. WHOQOL Group. (1995). The World Health Organization Project To Develop A Quality of Life Assessment Instrument (WHOQOL). Quality Of Life Research, 2, $153-159$.

[15]. WHOQOL Group (1995a): The World Health Organization Quality of life Assessment Instrument (the WH0Q0L); In OuaWy of Life Assessment: International Perspectives (Editors- Orley J, Kuyken W), Berlin, Springer- Verlag, p. 4157

[16]. Wilson, I.B. \& Clearly, P.D.(1995). Linking Clinical Outcomes With Health-Related QOL: A Conceptual Model Of Patient Outcomes. JAMA, 4, (273), 59-65)

[17]. http://sites.utoronto.ca/qol/qol_model.htm 